\title{
THE EYE IN THE EGYPTIAN MUMMY
}

BY

\author{
A. T. SANDISON, B.SC., M.D. \\ Department of Pathology, the University and Western Infirmary, Glasgow
}

Although the practice of mummification seems rather macabre and grotesque to modern man it was carried out in Ancient Egypt for a specific purpose. The intention was to preserve the body from the ravages of putrefaction, to maintain the identity of the dead man and, in later periods, to create a form which would resemble the embalmed God Osiris. The oldest preserved human bodies were not, in fact, deliberately mummified but desiccated by the dry, hot sand of the desert in which they were rudely buried. With the addition of an elaborate funerary equipment to formal tomb burial it became imperative that some other methods be devised to replace the simple desiccation of the earlier sand interments. It is probable that embalming did not begin until the dynastic period, and there is no doubt that various elaborations and sophistications were added from time to time.

The Egyptians left no contemporary accounts of the processes employed, and the only written evidence is to be derived from Herodotus and Diodorus Siculus.* The descriptions of Herodotus especially, have been frequently quoted and are probably in essentials reliable. Apart from these classical authors however, our knowledge of mummification is largely built up from observation of the mummies themselves. It is true to say that universal agreement has not yet been reached on some important points; e.g. whether the natron used was applied to the body in fluid or solid form. In the period when the practice was at its most elaborate it was customary to remove the brain through an opening in the ethmoid bone, and the abdominal and thoracic viscera (except the heart) through an abdominal incision which was placed in different sites at different periods. The brain, which was removed in pieces, was not very suitable for preservation but the other viscera were preserved, usually in so-called Canopic jars. An interesting account of the histological examination of such Canopic material is given by Shaw (1938).

It is well known that the eye, after death, soon looses the bright glistening appearance of the cornea, becomes dulled, and that the tension, of the anterior chamber in particular, falls so that the cornea becomes readily deformed. This is a process which is not readily checked even in the laboratory and the Egyptians made no attempt to preserve the globe. The usual

* Herodotus (484-406 B.c.). Book 2, Sections 85-88. Translations of the relevant passages from Diodorus Siculus (died A.D. 34) are given by Elliot Smith and Dawson (1924) and Ruffer ( $191 \mathrm{I})$. 


\section{The Eye in the Egyptian Mummy}

treatment was to pack the orbits with pads of linen on which the iris might be roughly painted. Over this the eyelids were closed; sometimes, however, the orbits were not packed although in the same mummies other elaborate techniques were employed, e.g. in the preservation of the finger-nails. Packing of the eye-sockets with linen has been noted in mummies of the Middle Kingdom described by Quibell (Elliot Smith and Dawson, I924).

Coming to the New Kingdom we note that, according to Elliot Smith (I912), an attempt was made to provide artificial eyes from linen for the mummy of Rameses III (20th Dynasty; died I 167 B.c.). For his successor, Rameses IV (died I 6 I B.c.) a remarkably successful cosmetic result was achieved by the insertion of small onions into the orbits; I am informed by Mr. Warren Dawson (personal communication, I957) that this is probably the only instance of the use of onions to simulate the eye. Dawson points out that the onion had undoubtedly some magic function in Egypt at this time. A return to linen, however, was made in the case of Rameses $\mathrm{V}$ (died I 57 B.c.). The mummies of some royal ladies of a slightly later period showed more elaborate attempts to simulate the eye by using stones. Thus Elliot Smith has described black and white stones used in the case of Queen Nedjmet and stones were also employed in the mummies of Queen Ma-ka-re, Queen Hent-tawy and Queen Nes-khons. Black and white stones were also noted by Elliot Smith in the mummy of Nes-ta-neb-asher; in the case of Djed-ptah-ef-ankh white stone eyes with an inlaid circular patch of black stone effectively represented the pupil and iris. In passing it may be mentioned that artificial eyes have also been described in mummies from Torres Straits and Polynesia where shells were utilized to give a life-like appearance.

I have been unable to trace any reference to a palaeo-histological study of the eye in the Egyptian mummy, although Ruffer (I9I I) mentions the presence of ocular muscles in one mummy, and of shrunken eyeballs in two others of 27-29th Dynasties on gross examination. He did, however, section the ocular muscles and optic nerves in bodies from several sand burials of the Greek period where the eyeballs themselves had disappeared. Williams (I927) has described ocular remnants from a Peruvian mummy (dating from about A.D. 700) but microscopy did not reveal anything of importance. This absence of studies is perhaps not surprising as the appearances of the orbits are singularly unpromising in mummy heads (see Fig. I). Nevertheless in pursuing some investigations on mummy palaeo-histology I treated an Egyptian mummy head with rehydrating fluid in order to obtain material for very large histological sections (method to be published later), and was surprised to notice that gradually the apparently empty orbits became occupied by an unfolding of tissue which eventually approached the space between the partly open lids. The remains were undoubtedly those of the anterior sclerotic with the greyish circular cornea regaining some of its 


\section{A. T. Sandison}

former translucency. The orbital contents were then removed en masse with the eyelids and surrounding facial skin. It immediately became obvious that only the anterior portions of the globe had survived, the posterior halves and the optic nerves having completely disappeared. Nevertheless in the remaining portions the characteristic melanin pigmentation of the inner coats was still quite apparent and traces of the irido-corneal angle were also present. The appearances from behind are seen in Fig. 2.

The material was left to harden for some time in 96 per cent ethyl alcohol, and then processed by a modification of the double-embedding method I have described (Sandison I955), using an automatic 'histokinette' machine. Sections were readily obtained after immersion of the paraffin block for a short time in Flatters and Garnett's softening fluid. Sections were stained by the haemalum and eosin, phosphotungstic-acid haematoxylin, and Weigert's elastica-Van Gieson methods. As usual in this type of material the remaining tissue is largely collagenous. Present in some sections are moulds of the ascomycetes group, possibly an aspergillus species, but these are almost certainly of modern origin as the detail is very good in sections stained by phosphotungstic-acid haematoxylin, and they are seen only on the superficial aspect of the material. Deep in the substance of the sclera numerous coccal and bacillary organisms are present; these, however, are less well stained, and probably represent the remains of putrefactive organisms which invaded the tissues shortly after death. Such organisms are commonly seen in mummified tissues. Also noted is an apparent intrusive larva in longitudinal section, presumably of some fly, and possibly a Piophila (see Fig. 3). Larvae and pupae are not uncommonly seen in mummified animals, and $I$ have found them in profusion on unwrapping a mummified cat, for example. These were identified by Messrs. H. Oldroyd and E. Britten as pupae of a Piophila genus fly and larvae of the beetle Dermestes maculatus. Attached to the remains of the globe, insertions of orbital muscles can be seen with skeletal muscle fibres, still showing cross striation, mingling with bundles of collagen and surrounded by well preserved adipose tissues. Nerves with the endoneurial collagen persisting are also present; these are presumably those supplying the extra-ocular orbital contents, most probably the external muscles of the eye. Also to be seen are the remains of collapsed blood vessels with the elastic lamina still quite readily discernible and stainable by Weigert's elastica method (see Fig. 4). The cornea is represented by a thin band of collagen which is constituted by several layers of fibrillary and rather convoluted appearance. On its inner aspect, in places, are detached areas of blue staining cells which appear to form coalescing sheets. The sclera is considerably thicker than the cornea and is composed of several distinct layers of thick collagen, some of rather spiral and others of a more reticulated appearance. In one layer fine fibrillary bands of collagen 


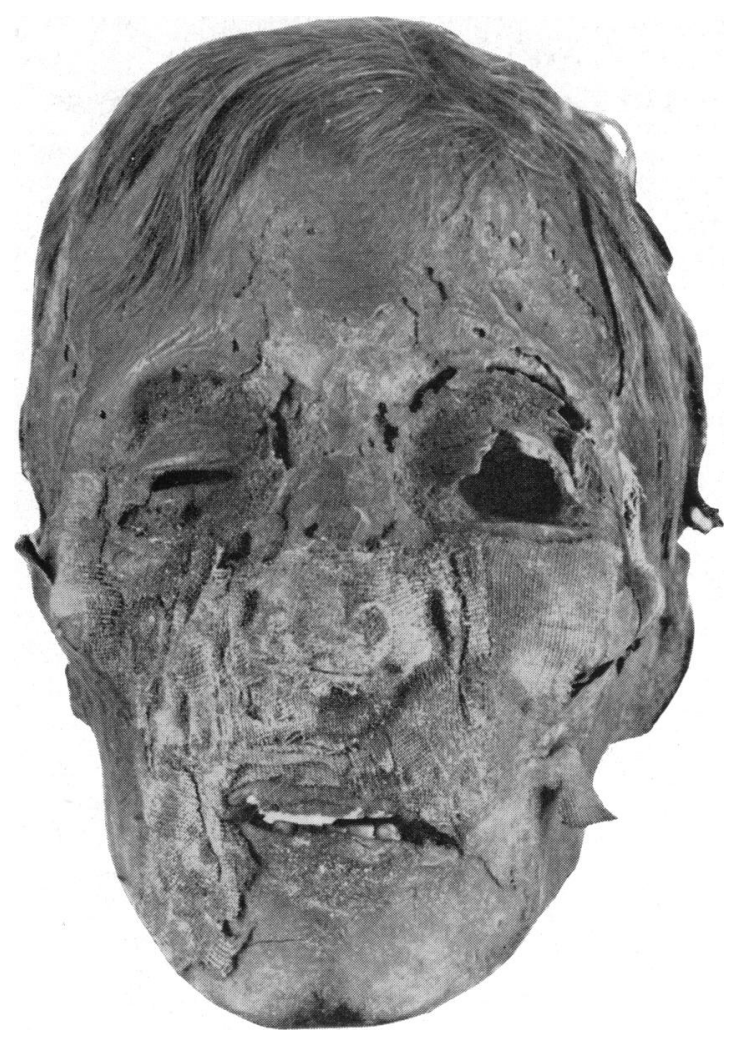

Fig. I.

Head of a male Egyptian mummy to show partially closed lids on the right side and apparently empty orbit on the left.
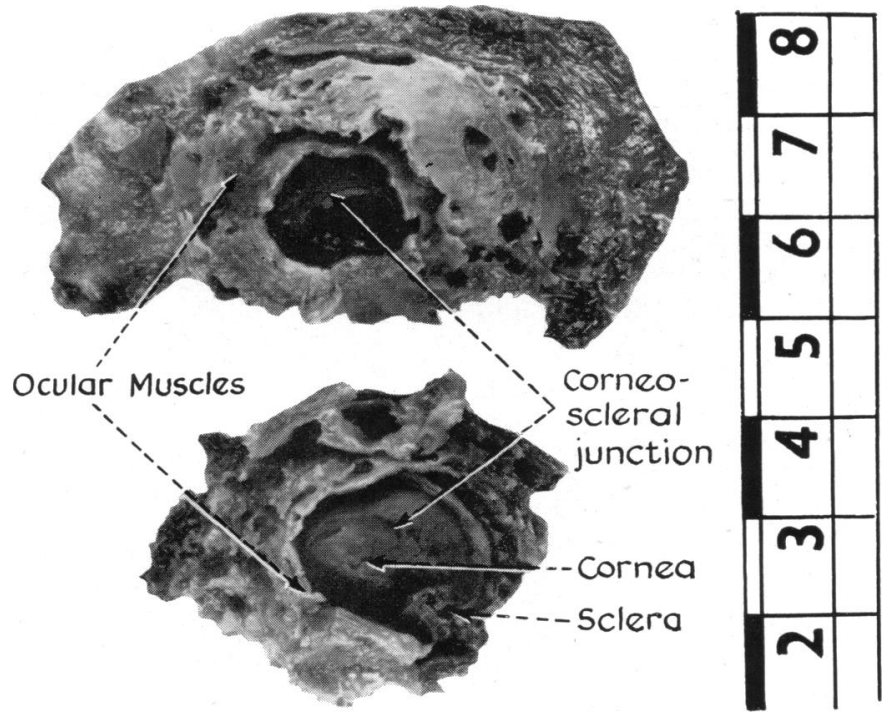

Fig. 2.

Orbital contents of another mummy head seen from behind after rehydration and removal. $\times \frac{5}{8} \mathrm{I} .3$. 


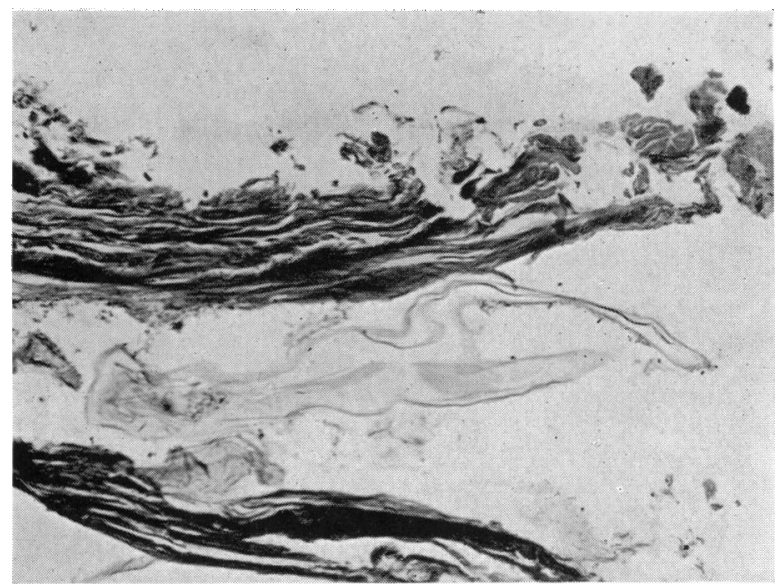

Fig. 3.

Intrusive larva seen in longitudinal section in the coats of the eye. This may be the developing larva of a Piophila fly. Phosphotungstic-acid haematoxylin stain. $\times$ I $5^{0}$.

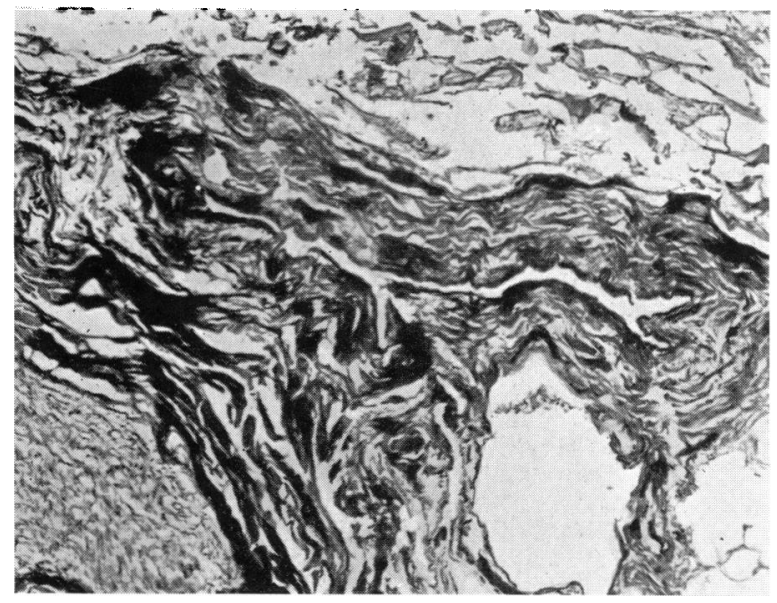

Fig. 4 .

Vein-artery-nerve complex, with the nerve seen in the lower left-hand corner the artery above and the vein to the right. Weigert's elastica-Van Gieson stain. $X$ I 50 .

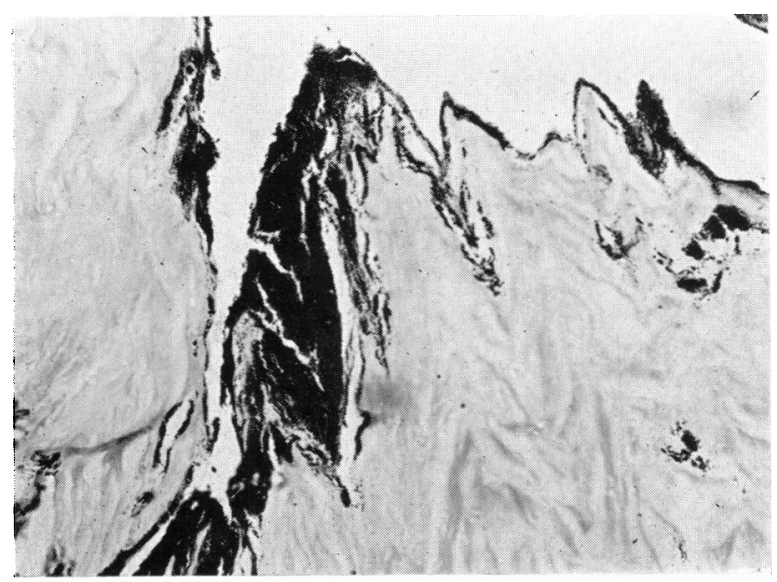

Fig. 5.

Inner aspect of eye showing melanin present in large amount in the ciliary region. Eosin stain. $\times 155$. 


\section{The Eye in the Egyptian Mummy}

and elastic tissue alternate. On the inner aspect of the globe, but absent from the cornea, and more abundant in the ciliary region, is a distinct layer of brownish-black melanin granules which stain characteristically dense black with Fontana's silver stain, and which is partially bleached by prolonged immersion in hydrogen peroxide solution. There is no doubt that this pigment is melanin which has persisted on the inner aspect of the eyeball after autolysis of the retinal and choroid coats (see Fig. 5).

The eyelids are remarkably well preserved and show a largely intact covering squamous epithelium with hair follicles, the eyelashes and the remains of tarsal glands in dense connective tissue. Adipose tissue and nerve trunks are also noted but the conjunctiva is lacking. Skeletal muscle can be distinguished but the striations here are poorly retained.

It may be mentioned here, that the head in question was that of an elderly man who showed calcification of the hyoid bone, and some alveolar absorption of the molar regions of the mandible on radiological examination.

\section{SUMMARY}

In the preparation of the Egyptian mummy no attempt was made to preserve the eyes, the orbits were often packed with linen and occasionally more sophisticated attempts were made to simulate eyeballs, e.g. by coloured stones. The demonstration of remains of the eyeball and other orbital contents in a mummy head is here reported. Undoubted melanin pigment was present in the eye.

\section{ACKNOWLEDGEMENTS}

My thanks are due to J. D. Boyd, Esq., of the Albert Institute Museum, Dundee, who provided the material for this research, to Mr. N. Russell for technical assistance and to Mr. W. Mason for the photographs.

I am also grateful to Mr. Warren R. Dawson for some very valuable information, and to Mr. C. Aldred, of the Royal Scottish Museum, for advice.

Messrs. H. Oldroyd and E. B. Britten of the British Museum (Natural History) kindly examined the entomological material described above.

\section{REFERENCES}

Elliot Smith, G. (ig12). 'The Royal Mummies.' Catalogue Général des Antiquités Egyptiennes du Musée du Caire. Cairo.

- ANd Dawson, W. R. (1924). Egyptian Mummies. London, Allen and Unwin.

Ruffer, M. A. (I9I I). 'Histological studies on Egyptian mummies.' Memoires Presentés à l'Institut Egyptien, Tome 6, Fascicle 3, 39 pp.

SANDIS ON, A. T. (I955). 'The histological examination of mummified material.' Stain Technol., 30, 277-83.

Sн A W, A. F . B. (1938). 'A histological study of the Mummy of Har-mosě, the singer of the eighteenth dynasty' (Circa I 490 B.c.), J. Path. Bact., 47, I I 5-23.

Williams, H. U. (1927). 'Gross and microscopic anatomy of two Peruvian mummies.' Arch. Path., 4, 26-33. 